\title{
Embodied Subjects and Fragmented Objects: Women's Bodies, Assisted Reproduction Technologies and the Right to Self-Determination
}

\author{
Jyotsna Agnihotri Gupta • Annemiek Richters
}

Received: 3 January 2008 / Accepted: 7 June 2008 / Published online: 2 September 2008

(C) The Author(s) 2008. This article is published with open access at Springerlink.com

\begin{abstract}
This article focuses on the transformation of the female reproductive body with the use of assisted reproduction technologies under neo-liberal economic globalisation, wherein the ideology of trade without borders is central, as well as under liberal feminist ideals, wherein the right to self-determination is central. Two aspects of the body in western medicine- the fragmented body and the commodified body, and the integral relation between these two-are highlighted. This is done in order to analyse the implications of local and global transactions in women's reproductive body parts for their right to self-determination and individual agency and what this means for their embodiment. We conclude by exploring whether women can become embodied subjects by exercising their proprietary right to their bodies through directing technology to achieve their own goals, while at the same time being
\end{abstract}

This article has been translated and adapted from the Dutch version published in the Tijdschrift voor Humanistiek, 2006; 26(7).

J. A. Gupta $(\bowtie)$

Gender and Diversity, University for Humanistics, P.O. Box 797, 3500 AT Utrecht, The Netherlands e-mail: j.gupta@uvh.nl

J. A. Gupta

International Institute of Asian Studies, Leiden University, Leiden, The Netherlands

A. Richters

Culture, Health and Illness,

Leiden University Medical Center,

Leiden, The Netherlands fragmented into parts and losing their personhood and bodily integrity.

Keywords Bioethics - Gender studies .

Women's bodies · Assisted reproduction technologies .

Self-determination

\section{Introduction}

In our post-modern times, developments in western medical science as well as information and communication technologies have forced us to abandon as obsolete the concept of the "natural" and "bounded" human body, actualising what was earlier thought to belong to the realm of science fiction alone. New technological advancements have made far-reaching interventions in the body possible, extending the boundaries of a single body beyond its skin, tissues and organs, so that we can even speak of post-human bodies, not only in cyberspace and virtual reality, but also in lived reality. Human beings have become an assemblage of body parts, which are exchanged, donated or traded. This development has raised new questions, for instance, about the status of the body and ownership of the body and its parts for bioethics, law, and feminism.

Our specific focus here is on the transformation of the female (potentially) "reproductive" body through the use of assisted reproduction technologies (ARTs) into a "productive" body, with marketable body parts. 
Originating in the West, in recent years these technologies have proliferated under neo-liberal economic globalisation, wherein the ideology of trade without borders is central, as well as under liberal feminist ideals, wherein the right to self-determination, choice and autonomy are ideals to strive for. While being globalised, these notions interact with local ideas about the body and (self) identity in a given society with varying conceptualisations in terms of claims regarding ownership. We will explore the kinds of interaction processes that take place. Our central question thereby is: Are women "agents" (subjects) in control over their own bodies and owners of its parts or are they "victims" (objects) of the new technologies and the actors and factors which drive their use? Considering that there are cross-cultural differences between women in their conceptualisations of selfhood and control over their bodies and lives, contrasting interpretations of the right to choose and self-determination are likely to emerge, particularly when it comes to proprietary rights over bodies and their parts.

In order to address our question we deal first with the role of biotechnology in fragmenting and commodifying the female reproductive body. Thereafter, we look at the (global) transactions in reproductive body partswhether in the form of donation or trade - and what this means for women's individual agency crossculturally. We use some examples from media reports as well as from the Internet (a transnational transactional space), in particular about practices in the United States of America (USA) where commercial transactions in reproductive body parts have become quite a common phenomenon and are driving globalisation in this field. Also, insights derived from empirical research in India by the first author are used to understand the process. We conclude by exploring whether women can become embodied subjects by exercising their proprietary right to their bodies through directing technology to achieve their own goals, while at the same time being fragmented into parts and losing their personhood and bodily integrity.

\section{The Creation of New Bodies through Biotechnology}

\section{The Fragmented and Fluid Body}

With developments in biotechnology, the metaphor of the body as a machine composed of parts, used in biomedicine since the eighteenth century, is reinforced. What is new is the replaceability of "flawed" body parts and their further objectification through transplantation medicine and reproductive medicine. In her formulation "organs without bodies", Braidotti (1989) refers to the discourse of biosciences, which, "in taking the organism as its object, also takes the body as a mosaic of detachable pieces". Under the biotechnological gaze which penetrates in three ways - x-rays and ultrasound, steel (instruments), and chemistry (biochemicals) - living organisms are reduced to an infinitesimal scale and lose all reference to the being as a whole. The shift in reproductive medicine is in intervening in the body from larger to smaller and yet smaller parts of the body; viz. entities such as the belly, uterus, eggs and embryos to microscopic parts-such as cells, genes and DNA - and also from semen to single sperm. Also, there is an objectification of the body through visualisation technologies. The technologies for pre-natal screening, such as ultrasound, create a division between the pregnant woman and the foetus, often privileging the latter (Rothman 1986) There is an increasing tendency to view women as wombs and childbearing machines, instead of whole persons. This attitude to women is particularly visible in the application of ARTs.

Just as with developments in transplantation medicine, with advances in reproductive medicine the boundaries of the body, in terms of closures at the skin and finiteness in terms of biological age, have been stretched, resulting in the open, flexible, leaky, fluid and unbounded body (Martin 1992; Shildrick 1997). While earlier the physical relationships between one human being and another were limited by relationships between bodies enclosed by boundaries of skin, now, relationships - real and virtual — are also through parts of bodies and the range of body parts that can be related is immense. "Our health and fertility are more likely to be owed to the therapeutic effects of another's fragments....We in turn will be obliged to donate what fragments we can afford" (Waldby 2002, 240). Such fragments are generally treated as detachable things, biological entities that are severed from social and subjective identity once they are removed from a particular body. New meanings of embodiment enabled by the transfer of body parts, including reproductive body parts, are being created. Matter from one body introduced into another's body as in organ, tissue or reproductive body part transfer is a literal form of 
"intercorporeality" (Weiss 1999). According to Waldby (op.cit. 245), Weiss' notion of "intercorporeality" suggests that the coherence of selfhood is constantly risked, fractured and transformed by virtue of the fact of being embodied in contemporary culture. It involves, a "material confusion of bodies", "a material indeterminacy" ("destabilisation of the self"), while producing relationality in terms of motherhood, fatherhood and kinship, and as such new forms of identity. Sometimes this relationality is based on ownership of the body or its parts and exchange of the same as commodity.

\section{The Commodified Body and the Body as Property}

Commodification of the body is not something new. Commodification of human corpses and body parts procured from the living and dead has a long history. Human material has value as trophies of war, religious relics, and therapeutic materials, medicinal and anatomical specimens (Sharp 2000; Lock 2001). Late modernity is witness to further commodification of the body within the medical market place. In addition, the body as a source of raw material for saleable products through the "human body shop" is now accessible globally (Kimbrell 1993; Andrews and Nelkin 1998).

In advanced capitalist societies commodification is characterised by the removal of boundaries between what can or cannot be bought and sold. Nowhere is this more dramatically illustrated than in the current markets for human organs, tissues and reproductive body parts to cater to a medical business driven by supply and demand. Economic relationships of various kinds are introduced into the social patterns of human reproduction. Commodities are "freed" from a direct relationship between producers and consumers; they are bought and sold and thus they can circulate in broader, even global networks. Within the emerging biotechnology industry human bodies have become "biological capital" that is deposited in bio (technology) banks (blood banks, sperm banks, embryo banks, gene banks, tissue banks, and cord blood banks) from which the public can draw. Along with these developments new desires and needs, new social ties and social contracts, and new conceptions of justice and ethics are being created (ScheperHughes 2000).

Property rights in reproductive material have led to legal battles. Not only ownership of children that may be born with the use of donor gametes, or through surrogacy, but even that of eggs and embryos, sperm and genes is sometimes publicly disputed. Law suits over the status of these body parts after the death of one parent or marital separation are fought out in courts, increasing the need for legislation regarding ownership and for legal interventions in specific cases. In some countries reproduction is regulated by contract law regarding ownership (property), patenting and use of embryos, genes and cells, etc. In the USA certain attorneys and law firms specialise exclusively in what is called Family Formation Law and Reproductive Law.

Discussions on commodification usually focus on the rights of ownership and control of one's body. Property right over one's body refers to two aspectsothers cannot appropriate parts of my body without my consent, but also I have the right to sell all or parts of my body. Another view is that I have no property right on my body: I can't alienate it, but it is a "commons" to which others may lay claim. ARTs raise questions such as: who owns the ova that are used for stem cell research, and whose genetic material is in the stem cell? Within stem cell research and cloning the egg is devoid of its original nucleus, then does it matter from whom the egg is derived? These questions become even more pertinent when it comes to discussions around the Human Genome Project. Are ova, sperm, cells and genes "persons", who are to be accorded the same rights as persons, or are they objects and thus to be treated as "things"?

What is also difficult is how to strictly define the lines separating various modes of transactionsdonation, gift, altruism, and commerce - in body parts. If this is the case for a country like the USA where contract law is highly advanced, it is perhaps even more so in countries where secular laws and ethics concerning the use of reproductive technologies have hardly been formulated and implemented. Notions of women's bodies and their parts as property may vary in different socio-cultural contexts. While examining possible modes of transactions in the following two sections, these differences are taken into account.

\section{Donation, Gift, Altruism or just Commerce?}

Drawing on the work of Mauss (1954), an important way of discussing the relations between individuals and groups in a given society has been in terms of the 
opposition between "gift" and "commodity", to characterise two orders of social relations. This opposition, however, has been critiqued as too simple. Frow (1997), for instance, posits that there is no pure type of either gift economy or commodity economy; rather the two are intertwined in various hybrid configurations. Gift and commodity are not mutually exclusive modes of transaction, since they tend to have in common certain forms of calculation, strategy and motivation. Gifts are not mere objects, but carriers of social bonds. Gift exchange establishes a qualitative relationship between the giver and the recipient, with the giver often acquiring some kind of power from the act of giving. Frow (ibid. 125) cites Gregory (1982) who argues that "a gift economy depends upon the creation of debt, where what is at stake is not the things themselves or the possibility of material profit but the personal relationships that are formed and perpetuated by ongoing indebtedness" Cheal (1988), also cited in Frow (ibid.) contrasts the short-term profits of the market economy to the longterm interest in sustaining social solidarity that drives the moral economy of interpersonal relationships. Within the latter, the social significance of individuals is defined by their obligations to others, with whom they maintain continuing relationships.

The following examples illustrate that the labour that goes into "the gift" is bought and paid for. Body parts are, nowadays, one's ultimate collateral-for instance, individuals sell a kidney to pay for the dowry of a daughter, male medical students "donate" (rather sell) sperm, and female students in the US and Spain sell their ova to pay their way through university (Croon 2004), or a woman in India decides to rent her womb to pay her invalid husband's medical bills. Commercial surrogacy (most developed in the USA), but also increasingly on the rise in India, has become another lucrative area to make money by exploiting women's bodies. These examples illustrate that the labour that goes into "the gift" is bought and paid for. Commercialism, however, can go hand in hand with what is called "compensated gifting", as women seem to be acting out of a sense of altruism, giving the precious "gift of life" to their unfortunate "sisters" who cannot fulfill their desire for a child otherwise.

In Indian society, where traditionally they have been socialised to be self-sacrificing, and to do everything to please others, "giving" seems to come "naturally" to women. Also, there is a certain amount of (moral) pressure on female relatives to volunteer as donors, whether it is of kidneys or eggs. As observed during the first author's empirical research in IVF clinics (Gupta 2006), most egg donors in India are relatives, just as most adoptions are trans-family adoptions. The donors are often younger sisters, cousins and sometimes sisters-in-law. While the bond between sisters is generally strong and harmonious in Indian society, relations between sisters-in-law are often tense. However, egg recipients were full of praise and gratitude for the sister-in-law who had volunteered to help out her husband's unfortunate sister. Donors, on the other hand, were happy that their body could be used for someone's benefit. Any transaction of money, if it occurred, was never mentioned by either donors or recipients to outsiders. However, according to the guidelines issued by the Indian Council of Medical Research in December 2004, egg donation among relatives or known friends of either the husband or the wife is to be banned, which is likely to increase trade in eggs and embryos. However, these guidelines did not achieve the status of legislation and both practices (donation and trade) continue, with the latter increasing openly. Some clinics also run egg-sharing ("donor-recipient") programmes where anonymous egg donors receive some compensation for their treatment costs from the couple they have donated to, if both are undergoing treatment under the same specialist who may bring the two together, generally in an anonymous relationship [ibid.]. Body parts can thus become the ultimate "gift" linking various members of the family, reaffirming familial expectations and love and consolidating relationships, or even creating new "family" formations, as in non-related donor and recipient dyads. Monetary compensation, if any, in the former cases is often blurred for outsiders.

The notion of semen, eggs and embryos as commodities is further confused by the fact that recipients themselves perceive the donor as having given them a precious "gift", in the form of a (potential) child which the women/couples happened to have paid for. The significance of social relations between the donor and recipient depend upon the fact whether they are known to each other or not, and whether the transaction is directly between the two parties or mediated (often commercially) by an outsider. Tober (2001) also questions whether any 
gift is driven by pure altruism. There is always some form of self-interest among donors - even when the gift is given freely and the donor remains anonymous; personal satisfaction may be the motivation rather than pure altruism. Egg donors in general feel fortunate to have their own children and, therefore, want to help infertile couples to experience that happiness. It gives women a sense of achievement, despite the physical discomfort. This is no different in the USA, although, the transactions there take place among unrelated donors and are explicitly commercial in nature. Comments from unrelated egg donors and surrogates found on the website Intendedparents. com, a facilitating agency in California for independent intended parents, surrogate mothers and egg donors, illustrate their motives. Apparently for them reciprocity and commercialisation can go well together, as also argued above by Frow (op.cit.) and Tober (op.cit.). Although, sometimes there seems to be a thin line between an altruistic "gift" (i.e. donation) and "commodity" (i.e. commerce), most transactions in body parts can be characterised (also) as trade, since exchange of money is involved, either directly between the donor and recipient or through a service provider/broker. The term "donation" is often a misnomer for what is actually a market transaction; it imbues it with a higher meaning. Besides, there is also a growing commerce in human body parts and substances.

\section{Trade in Human Body Parts and Substances}

As in transplantation medicine, advances in reproductive medicine have led to a lucrative trade in human body parts. The rapid growth of global capitalism and consumerism has created "new regimes of consumption". Bodies are seen as economic capital under conditions of neo-liberal economic globalisation. Scheper-Hughes $(2001,43)$ quotes George Soros (1998) who ascertained that "by their nature markets are indiscriminate, promiscuous and inclined to reduce everything, including human beings and their sexual and reproductive capacities to the status of commodities, things that can be bought, sold, traded and stolen." In the market transactions of reproductive body parts, biomedical research interests, business interests and sometimes also consumer interests come together. While the sale of solid organs is illegal in most countries, semen, ova, blood and other body fluids and tissues do not fall under the legislation because of their regenerative quality. Also, transactions in these body parts are relatively unregulated, primarily due to the ideology of individual autonomy.

The examples in the following section serve to illustrate, firstly, how women's maternal bodies and their products are expropriated and used within capitalist patriarchal structures for profit-making, and secondly, the role of the Internet in enabling (trans) national transactions in body parts.

\section{Body Fluids and Life forms as "Raw Materials" for Industrial Production}

In The Netherlands, an organisation called "Moeders voor Moeders" (mothers for mothers), whose folders can be found in all pharmacies, calls upon young pregnant women to help their less fortunate sisters, who have difficulty conceiving naturally. It collects the urine of young pregnant women for ten weeks between the sixth and sixteenth week of pregnancy. This urine contains hCG-a hormone which earlier could not be made synthetically. The Dutch multinational AKZO-Pharma makes fertility hormones and hCG pregnancy-test kits from this urine (Gupta 2000). It is clear that women give away free a natural resource that is at the basis of a product through which AKZO makes huge profits.

The question is: To what extent do bodily substances, tissues, secretions and organs, still belong to the body, thus resorting under a person's bodily self-determination, and when do they start becoming property capable of being transferred to new owners, like hospitals?

With respect to bodily self-determination, for example, it is obviously required that it be clear what counts as self, and what as other, where the boundaries of the individual body are drawn. In contemporary reproductive technologies, however, it is precisely these boundaries that are at stake and being redefined (van der Ploeg 1998, 58).

A placenta apparently belongs to the hospital, not to the mother and child who cooperated in creating it. Placentas are collected and delivered/sold to IVF embryology labs. In the 1990s there was a controversy regarding the sale of placenta by hospitals in 
England to Merieux, a cosmetics manufacturer. In China women were recruited to donate foetuses. Brain cells extracted from foetuses were being used to make a preparation to treat Parkinson's disease, in the belief that stem cells of embryos are able to develop in the brains of adults into dopamine producing cells, whereby Parkinson's disease can be slowed down. People were willing to pay up to US $\$ 10,000$ for such a concoction (Kimbrell op.cit.).

An application was submitted to obtain a patent for the characterisation of the gene sequence coding for human relaxin, a hormone which is synthesised and stored in female ovaries and helps in dilation, thus facilitating the birth process. A substance that naturally occurs in women's bodies was thus being treated as an 'invention' of three male scientists, Peter John Hud, Hugh David Nill, and Geoffrey William Tregear (Shiva 1994). There are reports of theft of ova from Croatian and Iranian clinics sold to research laboratories, and trade in eggs of Rumanian women to clients in Israel, the UK and the USA (de Volkskrant 2005). Women in developing countries of the global South or in the underdeveloped East European countries are more vulnerable to commercialisation of body materials, and even if provided compensation, they are likely to be paid much less than women in the developed North and West. The Internet has contributed immensely to the transnational trade in body parts.

\section{Internet and Trade in Body Parts}

Centres trading in human gametes-sperm, eggs, embryos - and surrogacy services can be found all over the world, and mainly in the USA. GIVF Cryobanks in Fairfax, Virginia, operating since 1986 offers wide facilities:

We are a full services cryobanking company, providing donor sperm, cord blood and embryo storage services as well as cryopreservation services for cancer patients. Our facilities have extensive experience shipping all over the world. As a division of the Genetics \& IVF Institute, the world's largest, fully integrated, specialised provider of infertility treatment and genetics services, GIVF Cryobanks is able to offer a depth and breadth of services that other facilities cannot match (www.GIVF.com).
Huntington Reproductive Center (HRC) in Southern California proclaimed proudly that as a result of their fertility treatments and highly trained physicians and staff, several thousand babies had been born across the USA and around the world. "In fact, we have HRC babies living on all continents except Antarctica!" (www.huntingtonreproductivecenter.com).

The Center for Surrogate Parenting and Egg Donation Inc. in Beverley Hills (CSP) in California (www.creatingfamilies.com) claims to have a world wide reputation as being the leader in the field of surrogacy. It claims further that there is no surrogacy agency that has been in business longer than CSP (operating since 1980); over the years CSP has been referred to as the "gold standard of the industry" or the "cadillac" of the industry, titles not self-proclaimed, but that were awarded to CSP. CSP offers hundreds of potential egg donors to choose from with the aid of photos and complete profiles regarding IQ and other characteristics. Based on this information couples can choose a donor and decide whether to come in contact with the donor and continue the acquaintance or not. At this centre eggs cost upwards of US $\$ 6,000$; donors receive US $\$ 2,500$ a piece. Its newsletter Intended Parents also carries articles by egg donors and surrogates who describe their experiences of having made a difference in someone else's life by having donated their eggs or acting as surrogates to realise another couple's dream. The websites of some centres even provide advertising space to individuals. Girls of Ivy League colleges in the USA can extract a premium of as much as ten times the market average for their eggs. Advertisers in college papers offer up to US $\$ 50,000$ for donors who meet the most demanding and specific criteria. Some centres, such as Ron's Angels, specialise in the eggs of fashion models, auctioning sperm and ova on their website (Goldberg 1999).

In July 2003, "Baby Donors" (www.babydonors. com), a company based in Amsterdam, claiming to be the first in Europe, was advertising its services on its website. It offered to act as an intermediary for the sale of tailor-made personalised sperm insemination and egg donor packages through the Internet. Sperm banks exist for a long time, but since a number of European countries, including The Netherlands, changed the law which had guaranteed anonymity to sperm donors, there is a shortage of sperm from "local" donors. This has resulted in the rise of sperm 
banks in countries where anonymity is still provided and their booming international operations [ibid.]. One of them is Cryos Sperm Bank, which is operating since 1987 and claims to be the world's largest provider of donor sperm with its head office in Aarhus, Denmark, with more than 200 donors available and almost 10,000 units of semen distributed each year. On its website the company claims to deliver sperm-related products to clinics or distributors in nearly 50 countries and donor semen to clinics in more than 40 countries (www.cryossperm bank.com). In India, most sperm donors are college students who sell their sperm to earn some pocket money (personal communication by the Director of Cryogenie India, a sperm bank in New Delhi). Cryogenie India, with its offices in New Delhi, Bangalore, and Jalna, is the largest provider of sperm preparation kits for intra-uterine insemination, and semen banking services in India. Sperm donors are paid US $\$ 40$ in Denmark and US $\$ 500$ in the USA (Alvarez 2004) and as little as US \$4-5 in India. The fastest growing clientele for sperm banks in the West are lesbian and single women choosing an anonymous donor, because known sperm donors often want to have a say in the upbringing of the child. This brings us to the question: What do these examples regarding transactions in reproductive body parts mean for the feminist ideal of women's right to selfdetermination with regard to their bodies, which originally had a different connotation?

\section{Women's Bodies and the Right to Self-Determination}

During the second feminist wave in the West in the 1970s, women, with their demand for women's right to self-determination regarding reproductive decisions, tried to wrest back control over their own bodies and lives that for ages had been denied to them by husbands, doctors, or the state. Initially, this referred to the demand for contraception and abortion as exemplified in the slogan-"women's body is women's right", or "baas in eigen buik" ("boss of one's own belly"), the slogan of the Dutch women's movement. However, since the 1980s liberal feminism made ownership by women of their own bodies the principal aim of women's liberation.
In her contributions "My Body, My Property" and "Feminist Perspectives on New Reproductive Technologies", Andrews (1986, 1987, cited in Mies (1988) widened the concept of "reproductive choice" to include an individual's choice to become pregnant through IVF, artificial insemination, or any other procedure. For Andrews "reproductive autonomy" comprises not only the option to use techniques like cryopreservation of eggs, sperm or embryos, but also the possibility of selling body parts to third parties. She criticised the legal practice in the USA that allowed people to donate their body parts but not to sell them, while scientists and doctors that experiment with body parts and substances usually obtain them free from the patients and often make great sums of money from the products of these experiments. By defining the human body as "property", the owner of the property could not only legally prevent the misuse of these parts, but also claim a share in the profits made by developing these into marketable commodities. Is it not patronising then to discourage or forbid women from selling their ova?, asks Andrews.

Since the 1980s, women's political struggles in the domains of reproductive rights have made the language of 'owning' or 'controlling' one's bodies a commonplace of feminist rhetoric.

But, this language has also been challenged, not only by conservatives and religious fundamentalists on the right but from within feminism; firstly on moral grounds by radical feminists, for whom such language evokes patriarchal and commercial practices of objectifying women's bodies, treating them as goods and second, on analytical grounds, by postmodernists, for whom such language rests on the illusion of agentic, coherent, physically bounded selves, writes Petchesky (1995, 387).

She argues that controversy over the "language of property" in feminist theory starts from a narrow premise that interprets property and ownership in terms of a "Lockean paradigm", of "property in one's person", signifying individualism, instrumentalism and a dualism between the body as commodity and the "person" as "transactor" (388). This would by 
corollary imply that the body is a commodity we own and thus we are free to sell our body parts or sexual and reproductive services in the marketplace. For instance, women can also use the body as property metaphor under the capitalist juridical system to assert their own autonomy over it, without interference. This is the case with egg-selling and commercial surrogacy in the USA. Using the "property in the person" argument, Dickenson (1997) affirms the liberatory potential of surrogacy, and therefore, sees prohibition of surrogacy contracts as limiting women's capacity to be treated as self-owning subjects of property, holding property in their bodies and reproductive capacities.

There remains uneasiness about using property notions to discuss human beings. Commenting on Andrews' position, Mies (op.cit.) points to the notions of rights and personhood in post-industrial societies, and biotechnology that have made "individuals" into "dividuals" and "reproducible fragments". Western capital associated with the patriarchal project of science and technology has turned everything, including people, into resources for appropriation. The female body with its generative power has been discovered as a new "area of investment" to overcome the "growth" problem of industrial capitalism. Under patriarchal capitalism women are seen as property and their bodies are owned by others, implying an alienation of women from their own bodies. This brings us to our main question regarding women's subjectivity and agency in processes and transactions within which their bodies are treated as objects.

Women: Agents, Victims, or Both?

The international women's movement has been divided in its response to ARTs and how far women are really free to choose. In some countries as in Israel, the pro-natalist ideology of compulsory motherhood makes reproduction a "national mission", while in others, like China and India, anti-natalist population policies influence reproductive decisions to limit the number of children to one or two in order to meet population control agendas. The help-seeking behavior of involuntary childless women is to be seen within the cultural constraints of femininity/motherhood, low self-esteem and gender power asymmetries. When confronted with their own or husband's infertility/sub-fertility, women seek ARTs to realise their desire for a child and to overcome stigmatisation, a sense of loss and self-esteem (Gupta 2000).

Fertility and motherhood (even more than fatherhood) are irrevocably linked with cultural notions about womanhood; this is more so in some cultures than in others. For many Indian women who often lack power from other sources, their reproductive capacity is an important source of power as biological motherhood is supposed to be the central axis of gender identity for adult women. In the Indian cultural context, for instance, the body is seen as a shared rather than a private resource. Being able to produce a child out of her body is not only important for a woman to achieve personal happiness, fulfillment and self-esteem but also esteem/status within the family and the treatment she will be meted out by other family members. Inability to conceive and bear a child often give rise to feelings of self-worthlessness, making her vulnerable to ill-treatment, violence and in extreme cases, abandonment by the husband and his family, and the loss of security of having a roof over her head. It explains the ease with which Indian women have adopted western biomedicine to give shape to their traditional cultural gender identities primarily as mothers, or as mothers of sons (through sex-selective abortions) [ibid.]. The enormous familial and social pressure on women has increased further with the availability of ARTs and explains the increasingly large numbers of women, ranging from the very young to the old who flock infertility clinics, as observed during the empirical research conducted by the first author (Gupta 2006).

Various studies done from a phenomenological perspective on embodiment let women "speak their bodies", or "write their bodily experiences" (Benjamin and Ha'elyon 2002), and in doing so explore how women negotiate a sense of self in relation to their bodies. We do not have bodies, but we are our bodies. Although, for instance, infertile women think of their bodies as machines, they also view their bodies as integral to their selves and often talk about infertility treatment as an invasion of the integrity of the self. Despite their objectification as part of medical procedures, women actively pursue their goals and try to negotiate control over their reproductive futures. They do not simply acquiesce to the medical portrayals of themselves; rather, they respond actively and strategically to achieve desired outcomes. They work the system and try to push medical treatment in 
the direction they want it to go (Greil 2002). Beckers' (2000) ethnography of infertile couples in the USA demonstrates that resorting to ARTs is about taking their lives in their own hands, to be like other "normal" married women with a fulfilled desire for children. This may involve receiving and donating eggs. Therefore, some question the ban on egg donation, viewing it as infringement upon women's rights to self-determination and discrimination against women, for, if sperm donation is allowed and men are paid for sperm, then why not egg donation, and why shouldn't women be paid for their ova? Certainly when this ideal is coupled with the ideal of altruism, that by making this choice they are also helping another woman/couple to realise their dream, then what is the problem? Should this not be seen as a new form of solidarity between women - a new form of "sisterhood"?

There are certain problems with the above reasoning. The arguments conflate sperm donation and egg donation as though obtaining sperm and ova are comparable procedures, which they are not. Women are hyper-ovulated to stimulate the production of a maximum number of ova and "egg harvesting" is done under anesthesia-procedures which could be risky for women's health. In biomedicine the female body is a factory within which women are labourers under the supervision of physician-managers. Within this factory model of reproduction it is the physician, not the "woman in the body", who is in control. Women as producers of eggs, the raw material for embryo research, as well as of children, fall under this supervision (Martin 1987). They deliver their bodies completely to the technology and to reproductive scientists. Some even say they feel as though their body belongs to someone else. In surrogacy, the contracting couple and infertility specialists temporarily own a woman's body. The woman is referred to as a (gestational) carrier, not as a woman, leave alone one who has a name, and her legal rights are subservient to that of the genetic parents. Although offered as a choice, the decision to sell body parts or rent a uterus is seldom made on the basis of full information regarding health hazards, or in absolute freedom. It can be a considered decision, but the decision is generally made in a context of limited possibilities for self-expression or development, rising unemployment, lack of financial resources, and in circumstances not always self-created. Family obliga- tions and poverty (joblessness and low income) appear to be the two main driving forces behind the transactions in reproductive body parts, including surrogacy, in India (Ghosh 2006). Also, illustrative is the recent case of a 22 year old orphan sold by an orphanage owner to a 48 year old farmer and general merchant in India under cover of "marriage" to be a surrogate for him and his childless wife (Kumar 2005).

Therefore, those women who decide to leave behind the image of being altruistic and self-sacrificing beings, and themselves seek the path of selling their body parts, are making themselves vulnerable to other, newer forms of exploitation. Women have become tools for the commercial interests of the fertility business, where biomedicine and profitmaking come together, which play upon the altruistic feelings of women - that women are or ought to be more altruistic than men - and (mis)use this. Women's reproductive labour is used to generate big profits for these firms and their allies in the trade. For some of those living on the margins of the global economy, who are daily assaulted by disease, hunger and premature death, and by degrading living and work conditions, and for whom the experience of bodily alienation is already a defining feature of their daily lives, the possibility of selling an organ seems like an act of empowerment, posits Scheper-Hughes (2001). The configuration of women's self-determination versus objectification through reproductive technologies depends on several factors, which vary across the world and in individual cases. Major factors are the nature of the social and structural constraints under which women live and the cultural values assigned to the body and (some) body parts, although these structures and values themselves appear to be shifting.

\section{Shifting Boundaries: Unresolved Issues for Bioethics}

Through globalisation women around the world are confronted with cosmopolitan biomedicine, which confronts local understandings of the body and its place within family and societal relations and local cosmologies. By facilitating greater degrees of intervention in the body, technology unsettles our knowledge of what bodies are and puts to test our ability to make moral judgements about how far science should 
be allowed to reconstruct the body. It raises fundamental questions regarding the ethics of the human body and its parts being traded within processes of globalisation, especially when, as George Soros (cited in Scheper-Hughes 2001, 46) indicated "global social values lag far behind global economics".

What is particularly remarkable in the exchange/ trafficking in reproductive body parts is that cultural ideas regarding the body as a temple, or as a holistic entity have become eroded in favor of the "universal codification" of the body as a machine with replaceable parts. We are witnessing "the erasure of cultural markers of the body as a sanctuary of human life and its replacement with new markers of body parts as objects that can be harvested for the sake of the prolongation of life" (Truong 2001, 7), and also for creation of new life as in technologically assisted reproduction, through "the mother machine", the image used by Corea (1985).

Cultural and religious notions about the sacredness, dignity (and integrity) of the body may sometimes be translated into bioethics or public laws devised by sovereign states relating to reproductive technologies. Laws may pose barriers to the global markets in body parts, but these have proven fragile, partly due to the boundary-lessness of the Internet and the ease of modern travel by which both bodies of ideas and bodies of persons cross boundaries.

The unregulated trade in body parts within and across countries raises issues concerning ownership and contestation over body parts, which show similarities with the trade in human bodies in previous forms of slavery. The imaginary of slavery has expanded from the labouring power to other utility roles of the human body. This similarity lies in the connection with production systems, despite the changing ideological structures. In capitalist production systems the cheap labour of some women is exploited to produce for the world market; in industrialised reproduction some women's reproductive capacity is exploited to produce for the global market. Women are now perceived as body-plantations and living tissue and cell banks, by others and sometimes also by themselves. Being reduced to providers of resources for the medical profession violates the human dignity of women (and men). We need to question this biomedicine which offers us dreams of immortality and imposes on us a relation- ship to one's body that is based on laying claims on the body parts of others.

What ARTs introduce is a new kind of alienation from one's body while allowing for a new kind of ownership. In Kantian terms, to regard one's own body as a property relation alienates one from the very basis on which humans can be said to enjoy a self, or to speak of one's self at all. ARTs add new aspects to old philosophical questions. What constitutes human essence and the self in the context of ARTs? What conception of human essence is presupposed in the value of bodily integrity? Is the concept of bodily integrity as a human right to be extended to (aborted) foetuses, which can be used to extract eggs, cells or other tissue? If the answer to the latter question is positive, feminists may find themselves having to begin once again where they started, to re-defend women's right to abortion.

Developments in Western bio-medicine in our postmodern times continually place before us challenges which oblige us to seek ways to work towards shared social values and ethical universals while keeping the diversity of cultural contexts in mind. Women as embodied beings give way to the alienation of themselves from their bodies and its parts and products. Their attempt to become subjects ("individuals") appears to be premised on their being reduced to fragmented objects ("dividuals"). By losing "the whole woman" in the relation between our own and others' body parts, have we not gone too far with what we wished to achieve with the second sexual revolution ushered in by assisted reproduction technologies?

Acknowledgements The research on the transaction in body parts for this article was conducted within a research project "Body parts, Property and Gender", funded by a grant from The Netherlands Foundation for the Advancement of Tropical Research (NWO-WOTRO), project number WB 52-871 during the first author's affiliation as post-doctoral researcher at Leiden University Medical Center.

This is an adapted version of the article earlier published in Dutch under the title "Belichaamde subjecten en gefragmenteerde objecten-Vrouwenlichamen, reproductieve technologieën en het recht op zelfbeschikking". Tijdschrift voor Humanistiek (Journal for Humanistics), July 2006; 26, 5-18.

Open Access This article is distributed under the terms of the Creative Commons Attribution Noncommercial License which permits any noncommercial use, distribution, and reproduction in any medium, provided the original author(s) and source are credited. 


\section{References}

Alvarez, L. 2004. Spreading Scandinavian Genes, Without Viking Boats, The New York Times, October 9.

Andrews, L., and D. Nelkin. 1998. Whose body is it anyway? Disputes over body tissues in a biotechnology age. Lancet 351: 53-57. doi:10.1016/S0140-6736(05)78066-1.

Becker, G. 2000. The elusive embryo: How men and women approach reproductive technologies. Berkeley: University of California Press.

Benjamin, O., and H. Ha'elyon. 2002. Rewriting fertilization: Trust, pain, and exit points. Women's Studies International Forum 25(6): 667-678. doi:10.1016/S0277-5395(02) 00350-3.

Braidotti, R. 1989. Organs without bodies. Differences. Journal of Feminist Cultural Studies 1(1): 147-161.

Corea, G. 1985. The mother machine: Reproductive technologies from artificial insemination to artificial wombs. New York: Harper \& Row.

Croon, M. 2004. Een eicel uit Spanje, NRC Handelsblad, July 24.

de Volkskrant. 2005. Eicelhandel Roemenië verdacht (Dubious trade in eggs in Rumania), March 9.

Dickenson, D. 1997. Property, women and politics: Subjects or objects? Cambridge: Polity Press.

Frow, J. 1997. Time and commodity culture: Essays in cultural theory and post-modernity. Oxford: Clarendon Press.

Ghosh, Aditya. 2006. Cradle of the world. The Hindustan Times, December 24.

Goldberg, Cary. 1999. For sale on internet: Fashion models' Eggs, International Herald Tribune, October 5.

Greil, A.L. 2002. Infertile Bodies: Medicalization, metaphor and agency. In Infertility around the Globe: New thinking on childlessness, gender, and reproductive technologies, eds. C. Marcia, C. Inhorn, and F. van Balen, 101-118. Berkeley: University of California Press.

Gupta, J.A. 2000. New reproductive technologies, Women's Health and Autonomy: Freedom or dependency? New Delhi: Sage.

Gupta, J.A. 2006. Towards transnational feminisms: Some reflections and concerns in relation to the globalization of reproductive technologies. European Journal of Women's Studies 13(1): 23-38. doi:10.1177/1350506806060004.

Kimbrell, A. 1993. The Human Body Shop: The engineering and marketing of life. San Francisco: Harper Collins Publishers.

Kumar, Lalit. 2005. Orphan sold for rupees 71,000 to bear child, The Times of India, February 17.

Lock, M. 2001. The alienation of body tissue and the biopolitics of immortalized cell lines. Body \& Society 7 (2-3): 63-91. doi:10.1177/1357034X0100700204.

Martin, E. 1987. The woman in the body. A cultural analysis of reproduction. Boston: Beacon Press.

Martin, E. 1992. The end of the body? American Ethnology 19: 121-140. doi:10.1525/ae.1992.19.1.02a00070.

Mauss, M. 1954. The gift. London: Routledge.
Mies, M. 1988. From the Individual to the Dividual: In the supermarket of "reproductive alternatives". Reproductive and Genetic Engineering 1(3): 225-237.

Petchesky, R.P. 1995. The body as property: A feminist revision. In Conceiving the New World Order: The global politics of reproduction, eds. F.D. Ginsburg, and R. Rapp, 387-406. Berkeley: University of California Press.

Rothman, B.K. 1986. The tentative pregnancy: Prenatal diagnosis and the future of motherhood. New York: Viking.

Scheper-Hughes, N. 2000. The global traffic in human organs. Current Anthropology 41(2): 191-224. doi:10.1086/ 300123.

Scheper-Hughes, N. 2001. Commodity fetishism in organs trafficking. Body \& Society 7(2-3): 31-62. doi:10.1177/ 1357034X0100700203.

Sharp, L.A. 2000. The commodification of the body and its parts. Annual Review of Anthropology 29: 287-328. doi:10.1146/annurev.anthro.29.1.287.

Shildrick, M. 1997. Leaky bodies and boundaries. Feminism, postmodernism and (bio)ethics. London: Routledge.

Shiva, V. 1994. The seed and the earth: Biotechnology and the colonization of regeneration. In Close to Home: Women reconnect ecology, health and development, ed. V. Shiva, 128-143. London: Earthscan Publications.

Tober, D.M. 2001. Semen as gift, semen as goods: Reproductive workers and the market in altruism. Body \& Society 7 (2-3): 137-160. doi:10.1177/1357034X0100700205.

Truong, T. 2001. Human trafficking and organised crime. Working Paper Series No. 339, July, The Hague: Institute of Social Studies.

van der Ploeg, I. 1998. Prosthetic bodies. Female embodiment in reproductive technologies. $\mathrm{PhD}$ Thesis, Maastricht University.

Waldby, C. 2002. Biomedicine, tissue transfer and intercorporeality. Feminist Theory 3(3): 239-254. doi:10.1177/ 146470002762491980.

Weiss, G. 1999. Body images: Embodiment as intercorporeality. London: Routledge.

Web sources http://www.babydonors.com (first accessed on 26 November 2003, again on 2 January 2008). After being prosecuted for operating in violation of the Dutch Embryo Law which bans the commercial availability of sperm, eggs and embryos the website has discontinued these activities and now sells only products for baby care. http:// www.creatingfamilies.com. This is the website for the Center for Surrogate Parenting and Egg Donation Inc.com (first accessed on 1 August 1998, again on 2 January 2008). http://www.cryosspermbank.com (first accessed on 10 October 2004 and again on 28 December 2007). http:// www.GIVF.com (first accessed on 1 August 1998, again accessed on 2 January 2008). http://www.huntingtonrepro ductivecenter.com (first accessed on 1 August 1998, again on 2 January 2008). http://www.intendedparents.com, on 3 July 2002, again on 2 January 2008. 